Canadian

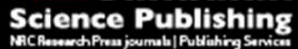

Canadian Journal of Physiology and Pharmacology Revue canadienne de physiologie et pharmacologie

\title{
Protective effects of Tempol in an experimental ovarian ischemia-reperfusion injury model in female Wistar Albino rats
}

\begin{tabular}{|r|l|}
\hline Journal: & Canadian Journal of Physiology and Pharmacology \\
\hline Manuscript ID & cjpp-2016-0309.R3 \\
\hline Manuscript Type: & Article \\
\hline Date Submitted by the Author: & 21 -Dec-2016 \\
\hline Complete List of Authors: & $\begin{array}{l}\text { Pınar, Neslihan; Mustafa Kemal Universitesi; Mustafa Kemal Universitesi } \\
\text { Soylu Karapınar, Oya; Mustafa Kemal Universitesi Tip Fakultesi } \\
\text { Özcan, Oğuzhan; Mustafa Kemal Universitesi Tip Fakultesi } \\
\text { Atik Doğan, Esin; Mustafa Kemal Universitesi Tip Fakultesi } \\
\text { Bayraktar, Suphi; Mustafa Kemal Universitesi Tip Fakultesi }\end{array}$ \\
\hline Keyword: & Ovarian ischemia-reperfusion, Tempol, oxidatife stress \\
\hline & \multicolumn{2}{|l}{} \\
\hline
\end{tabular}

\section{SCHOLARONE" \\ Manuscripts}


Protective effects of Tempol in an experimental ovarian ischemia-reperfusion injury model in female Wistar Albino rats.

Neslihan Pınar ${ }^{1}$, Oya Soylu Karapınar ${ }^{2}$, Oğuzhan Özcan ${ }^{3}$, Esin Atik Doğan ${ }^{4}$, Suphi Bayraktar ${ }^{5}$

${ }^{1}$ Department of Medical Pharmacology, School of Medicine, Mustafa Kemal University, Hatay, Turkey

${ }^{2}$ Department of Obstetrics and Gynaecology, School of Medicine, Mustafa Kemal University, Hatay, Turkey

${ }^{3}$ Department of Biochemistry, School of Medicine, Mustafa Kemal University, Hatay, Turkey

${ }^{4}$ Department of Pathology, School of Medicine, Mustafa Kemal University, Hatay, Turkey

${ }^{5}$ Department of Medical Microbiology, School of Medicine, Cukurova University, Adana, Turkey

Corresponding Author

Dr. Neslihan Pinar

Address: Mustafa Kemal University, Faculty of Medicine, Medical Pharmacology, Hatay 01330, Turkey

Telephone: 0326 2291000-3157

E-mail: drnesli01@gmail.com

npinar@,mku.edu.tr 


\section{A B S T R A C T}

The aim of this study was to investigate the antioxidant effects of tempol on ovarian ischemiareperfusion injury in rats. Forty female Wistar albino rats were randomly divided into five groups: Group I: sham, Group II: ischemia (I), Group III: ischemia-reperfusion (I/R), Group IV: ischemia-reperfusion (I/R) + Tempol $30 \mathrm{mg} / \mathrm{kg}$ i.p, Group V: ischemia-reperfusion + Tempol $50 \mathrm{mg} / \mathrm{kg}$ i.p. Oxidative Stress Index (OSI) was significantly higher in the ischemia group and the $\mathrm{I} / \mathrm{R}$ group compared with the sham group. Catalase levels were significantly lower in the I/R group than in the I/R + Tempol $30 \mathrm{mg} / \mathrm{kg}$ i.p. and the I/R + Tempol $50 \mathrm{mg} / \mathrm{kg}$ i.p. group. Glutathione peroxidase levels were lower in the $I / R$ group than in the $I / R+T e m p o l$ $30 \mathrm{mg} / \mathrm{kg}$ i.p. and the $\mathrm{I} / \mathrm{R}+$ Tempol $50 \mathrm{mg} / \mathrm{kg}$ i.p. group. MDA levels were significantly lower in the $\mathrm{I} / \mathrm{R}+$ Tempol $30 \mathrm{mg} / \mathrm{kg}$ i.p. group and the $\mathrm{I} / \mathrm{R}+$ Tempol $50 \mathrm{mg} / \mathrm{kg}$ i.p. group than in the $\mathrm{I} / \mathrm{R}$ group. The levels of the histopathological parameters were significantly decreased in the $\mathrm{I} / \mathrm{R}+$ Tempol $50 \mathrm{mg} / \mathrm{kg}$ i.p. group compared with the I/R group. Tempol can be used for reducing ovarian ischemia reperfusion injury.

Key words: Ovarian ischemia-reperfusion, Tempol, oxidative stress 


\section{INTRODUCTION}

Ovarian torsion is an urgent gynecological event that mostly occurs in women of reproductive age (Oelsner and Shashar 2006). Ovarian torsion has a prevalence of $2.7 \%$ in gynecological emergency (Hibbard 1985). A reduction in ovarian blood flow may lead to ovarian necrosis, ischemia, and infarction (Keskin et al. 2015). Early diagnosis and treatment of ovarian torsion are crucial for the protection of ovarian function. Moreover, a delay in the diagnosis and treatment may cause ovarian loss and infertility (Dokuyucu et al. 2014; Halici et al. 2008).

The primary pathophysiologic mechanism in ovarian torsion is ischemia followed by reperfusion that causes ischemia-reperfusion (I/R) injury in the ovaries. Reactive oxygen species (ROS) such as superoxide anion, hydrojen peroxide and hydroxyl radicals are formed after reperfusion. Reactive oxygen species cause DNA damage, cell membrane, and mitochondrial damage via lipid peroxidation and cytokine production from activated neutrophils and ultimately lead to tissue damage. Accumulation of polymorphonuclear leukocytes $(\mathrm{PMN})$ into ovarian tissues is characterized by acute inflammation and shows action of chemotactic mediators. Therefore, several anti-inflammatory and antioxidant free radical scavenger agents have been used to protect the tissues against I/R injury (Cosar et al. 2007; Oral et al. 2011).

Tempol (4-hydroxy2,2,6,6-tetramethylpiperidine-N-oxyl) is a membrane-permeable radical scavenger which can protect tissues against oxidative stress (Karatas et al. 2004). Tempol is a low molecular weight antioxidant that has a superoxide dismutase (SOD) mimetic activity and scavenges superoxide anion $\left(\mathrm{O}_{2}\right)$ (Abouzied et al. 2016). Administration of tempol significantly reduces organ injuries caused by I/R. These organs include gastric mucosa, gall bladder, intestine, myocardium, kidney and liver (Abdallah et al. 2009; Fujii et al. 2005; Gomez-Pinella et al. 2010; McCormick et al. 2006; Sepodes et al. 2004; Teke 2008). The beneficial effects of tempol depend on the scavenging hydroxyl radicals within the cell and are reported to reduce tissue damage due to inflammation (Erbis et al. 2015). Tempol removes ROS and inhibits lipid peroxidation, and all of these processes play a major role in the inhibition of oxidative injury (Zhao et al. 2015).

In this study, we aimed to investigate the antioxidant effects of tempol on ovarian $\mathrm{I} / \mathrm{R}$ injury in an experimental rat model. We measured the total oxidant status (TOS), total 
antioxidant status (TAS), oxidative stres index (OSI), catalase activity (CAT), glutathione peroxidase activity (GSH-Px), and malondialdehyde (MDA) levels biochemically and we collected the ovarian tissues for histopathologic analysis.

\section{MATERIALS AND METHODS}

\section{Animals}

This study was approved by Mustafa Kemal University Animal Ethics Committee (Approval No. 2015/4-11). Forty female Wistar albino rats aged 12 weeks, weighing 250-300 g, were obtained from Mustafa Kemal University Experimental Animal Laboratory and were included in the study. The rats were caged individually under controlled environmental conditions with $20-22{ }^{\circ} \mathrm{C}$ temperature and humidity and with a 12 -h light/dark cycle and were fed ad libitum. The rats were separated randomly into five groups with eight rats each: Group I: sham, Group II: ischemia (I), Group III: ischemia/reperfusion (I/R), Group IV: I/R+ Tempol $30 \mathrm{mg} / \mathrm{kg}$, Group V: I/R + Tempol $50 \mathrm{mg} / \mathrm{kg}$.

\section{Chemicals}

Tempol (4 hydroxy tempo) was obtained from Sigma Chemical Co. (St. Louis, MO, USA). Ketamine hydrochloride was obtained from Pfizer (Turkey) and xylazine hydrochloride was obtained from Bayer (Turkey).

\section{Experimental protocol}

Each rat was weighed and anesthetized with intramuscular ketamine hydrochloride $(50 \mathrm{mg} / \mathrm{kg}$ Ketalar; Eczacibasi, Istanbul, Turkey) and xylazine hydrochloride $(10 \mathrm{mg} / \mathrm{kg}$ Rompun; Bayer Türk İlaç Ltd., Istanbul). The rats were placed in the dorsal recumbent position. A $1.5 \mathrm{~cm}$ midline longitudinal laparotomy incision was made under sterile conditions. The abdomen was opened and the large intestines were separated attentively and removed out of abdomen. The uterine horns and adnexa were observed for 1 minute in the Sham group and then closed with 3-0 surgical suture (Ergun et al. 2010). In the experimental groups (Group I-V), vascular clamps were placed just beneath the ovaries and over the uterine horns to provide total ischemia. Incisions were closed with $4 / 0$ silk suture. 
In group II (Ischemia group), ischemia was induced for 3 hours using a torsion model stimulated by the application of a traumatic vascular clamp to the vascular pedicle $1 \mathrm{~cm}$ above and below the ovary. The incision was closed with $4 / 0$ silk suture. In group III (I/R group), ischemia was performed for 3 hours, followed by reperfusion for 3 hours. In group IV (I/R and Tempol $30 \mathrm{mg} / \mathrm{kg}$ i.p. group), ischemia was induced for 3 hours as in Group II, followed by the administration of Tempol $30 \mathrm{mg} / \mathrm{kg}$ i.p. $30 \mathrm{~min}$ prior to 3 hours of reperfusion. In group V (I/R and Tempol $50 \mathrm{mg} / \mathrm{kg}$ i.p. group), Tempol $50 \mathrm{mg} / \mathrm{kg}$ i.p. was administered 30 min prior to 3 hours of reperfusion.

After surgery, all the rats were sacrificed. Blood samples were obtained through cardiac puncture and centrifuged at $1,500 \mathrm{x} g$ for 10 minutes. Supernatants were portioned and stored at $-80{ }^{\circ} \mathrm{C}$. Both ovaries were extirpated. One of the ovaries from each rat were stored in a freezer at $-80{ }^{\circ} \mathrm{C}$ for biochemical analysis and the other was fixed in formaldehyde solution $10 \%$ for histological examination.

\section{Biochemical analysis}

The ovarian tissues were weighed and homogenized in ice-cold phosphate-buffered saline at $\mathrm{pH} 7.4(10 \% \mathrm{w} / \mathrm{v})$ and centrifuged at $1,500 \mathrm{x} \mathrm{g}$ for $15 \mathrm{~min}$ at $4^{\circ} \mathrm{C}$. Supernatants were removed for analysis. Protein content of supernatants was determined by Bradford method using bovine serum albumin as standard (Bradford 1976).

\section{Serum TOS, TAS and OSI levels}

Serum total oxidant status (TOS) and total antioxidant status (TAS) were measured by using a novel automated colorimetric method developed by Erel (Erel Assay Diagnostics kits, Mega Tip, Turkey) (Erel 2004; Erel 2005). The TOS results were expressed as micromolar hydrogen peroxide equivalent per liter $\left(\mu \mathrm{mol} \mathrm{H}_{2} \mathrm{O}_{2} \mathrm{Eq} / \mathrm{l}\right)$ and the TAS levels were expressed as mmol Trolox Eq/l. The ratio of TOS to TAS was accepted as the oxidative stress index (OSI) and was calculated as follows: OSI (arbitrary unit) =TOS $\left(\mu \mathrm{mol} \mathrm{H}_{2} \mathrm{O}_{2} \mathrm{Eq} / \mathrm{l}\right) / \mathrm{TAS}$ ( $\mu$ mol Trolox Eq/l) x 100 (Demirbag 2007). 


\section{Antioxidant enzyme activities}

\section{Catalase activity (CAT)}

Catalase activity was estimated by the method of Aebi (Aebi 1973). The decomposition of the substrate $\mathrm{H}_{2} \mathrm{O}_{2}$ was monitored spectrophotometrically at $240 \mathrm{~nm}$ (Schimadzu UV 1601, Japan). Activity was calculated from the change in absorbance and finally expressed as $\mathrm{k} / \mathrm{g}$ tissue [k: rate constant of the first order reaction as defined by Aebi].

\section{Glutathione peroxidase activity (GSH-Px)}

GSH-Px activity was measured by the method of Paglia and Valentine (Paglia and Valentine 1967). Enzymatic reaction was initiated by adding $\mathrm{H}_{2} \mathrm{O}_{2}$ to the reaction mixture containing reduced glutathione, reduced nicotinamide adenine dinucleotide phosphate, and glutathione reductase. The change in the absorbance at $340 \mathrm{~nm}$ was monitored by a spectrophotometer. One unit of GSH-Px was defined as micromoles of NADPH oxidized per minute. Activity was given in units per gram tissue.

\section{Malondialdehyde (MDA) levels}

The MDA levels in homogenized tissues were measured by the double-heating method of (Draper and Hadley 1990). This method is based on spectrophotometric measurement of the end product of lipid peroxidation with thiobarbituric acid at $532 \mathrm{~nm}$. The calibration curve was constructed by using commercially available MDA equivalents (1,1,3,3tetramethoxypropane, Lot no, MKBP9901V, Sigma-Aldrich). MDA results were expressed as $\mathrm{nmol} / \mathrm{g}$ tissue.

\section{Histopathological analysis}

Ovarian tissues were fixed in $10 \%$ neutral formalin solution for 24 hours. The tissue samples were embedded in paraffin wax and sectioned at $4 \mu \mathrm{m}$, and stained with hematoxylin and eosin. A light microscope (Olympus Clinical Microscope BX53, Tokyo-Japan) was used to analyze all sections. The criteria for ovarian injury included presence of vascular congestion, hemorrhage, edema, infiltration of inflammatory cells, and follicular cell 
degeneration. The findings classified for each parameter were as follows: Grade 0, no findings; Grade 1, findings $<33 \%$; Grade 2: findings of 33-66\%; and Grade 3, findings $>66 \%$ (Guven et al. 2010).

\section{Statistical analysis}

Continuous variables were expressed as mean \pm standard deviation (SD). The groups were compared by using One-Way Analysis of Variance (ANOVA) followed by Tukey's HSD test. A $p$ value of $<0.05$ was considered significant. Statistical analyses were performed by using SPSS 21.0 for Windows (SPSS Inc., Chicago, IL, USA).

\section{RESULTS}

Table 1 presents mean TAS, TOS and OSI levels for each group. TAS values were lower in Group II ( $p=0.042)$ compared with Group I. TOS values were significantly higher in Group II $(p=0.034)$, Group III $(p<0.001)$, and Group IV $(p=0.001)$ compared with Group I. TOS values were lower in Groups IV and V compared with Group III $(p<0.001)$. TOS values were lower in Group V $(p=0.013)$ than in Group IV.

In addition, OSI values were significantly higher in Group II (4.28 $\pm 0.38, p=0.002)$, Group III $(7.87 \pm 0.32, p<0.001)$ and Group IV $(4.92 \pm 0.37, p=0.001)$ compared with Group I $(2.81$ $\pm 0.3)$. OSI values were significantly higher in Group III $(7.87 \pm 0.32, p<0.001)$ than in Group II $(4.82 \pm 0.38, p=0.002)$ and were significantly lower in Group IV $(4.92 \pm 0.37, p<0.001)$ and Group V (3.74 $\pm 0.31, p=0.034)$ compared with Group III $(7.87 \pm 0.32, p<0.001)$.

Table 2 presents tissue MDA, CAT, GSH levels. Tissue MDA levels were significantly higher in Groups II, III, IV, and V than in Group I $(p<0.001)$ and were statistically higher in Group III than in Group II $(\mathrm{p}<0.001)$. Moreover, the MDA levels were significantly lower in Group IV and Group V than in Group III $(p<0.001)$.

Catalase levels were highest in Group I and were significantly higher in Group I than in groups II, III, IV, and V ( $p<0.001)$. Catalase levels were significantly lower in Group III than in Groups IV and V $(p<0.001)$.

GSH-Px levels were highest in Group I and were significantly higher in Group I than in Groups II, III, IV, and V ( $p<0.001)$. GSH-Px levels were significantly lower in Groups III, IV, and V than in Group II $(p<0.001)$. 


\section{Histopathological changes of groups}

Figure 1 presents the histopathologic examination of ovarian tissue samples of the experimental groups. Edema formation was significantly increased in Group III $(p=0.001)$ compared with Group I.

Vascular congestion was significantly increased in Group II $(p=0.017)$ and III $(p=0.001)$ compared with Group I, whereas it was significantly decreased in Group V compared with Group III $(p=0.017)$.

Hemorrhage was significantly increased in Group III $(p<0.001)$ compared with Group I and was significantly decreased in Group V $(p=0.005)$ compared with Group III.

Infiltration of inflammatory cells was significantly increased in Group III $(p<0.001)$ compared with Group I and was significantly decreased in Group V $(p<0.001)$ compared with Group III. No follicular degeneration was detected in any group. Table 3 presents the pathological findings of each group $(p<0.05)$.

\section{DISCUSSION}

Ovarian torsion remains a significant clinical problem for the women in reproductive age. It not only affects reproduction but also causes infertility if not treated. The present study indicated dose-dependent antioxidant effects of tempol on ovarian $I / R$ injury in an experimental rat model. $\mathrm{I} / \mathrm{R}$ injury leads to biochemical and histological changes in ovarian tissues. Ischemia (i.e. insufficient blood flow and lack of oxygen) not only decreases ATP production but also increases lactic acid production and accumulates lipid peroxidase in tissues (Dokuyucu et al. 2014). After reperfusion of the ovarian tissues, reactive oxygen species such as hydroxyl radical $(\mathrm{OH})$, superoxide anion $\left(\mathrm{O}_{2}^{-\cdot}\right)$, pro-radical hydrogen peroxide $\left(\mathrm{H}_{2} \mathrm{O}_{2}\right)$, and reactive nitrogen species (RNS) are formed by the restoration of blood flow. Ischemia-reperfusion leads to accumulation of proinflammatory mediators that cause tissue necrosis. Reactive oxygen species stimulate neutrophils and can cause further damage to the cells of ischemic tissues, mainly due to lipid peroxidation in cellular and mitochondrial membranes (Ozat et al. 2009; Sahin et al. 2008; Somuncu et al. 2008; Zweier 1987). Reactive oxygen species also attack DNA in the nucleus and destruct cell membrane (Sadoshima 2008). 
MDA, which is a metabolite of the ROS-mediated lipid peroxidation cascade, is a highly toxic molecule and shows oxidative stress. MDA is a marker of tissue injury and also induces destruction of polyunsaturated fatty acid in the cell membrane. MDA level significantly increases in I/R injury, suggesting wall fluidity and permeability of the damaged cell ${ }^{32}$. In our study, tissue MDA levels were significantly higher in Group III, and the MDA levels were significantly lower in Group IV and Group V than in Group III. Kurt et al. also demonstrated that the MDA levels indicating oxidative stress significantly decreased in the colchicineadministered group, similar to our study (Keskin et al. 2015).

Cells protect themselves from ROS injury via intracellular enzymes such as SOD, catalase and GSHPx (Keskin et al. 2015). Catalase is an antioxidant enzyme that scavenges the cell from pro-radical hydrogen peroxide $\left(\mathrm{H}_{2} \mathrm{O}_{2}\right)$. In our study, catalase was used for the determination of antioxidant level. The results revealed that catalase significantly increased in Group IV and Group V compared with Group III. Similarly, glutathione peroxidase levels were significantly increased in Group IV and Group V compared with Group III.

TOS values were significantly higher in Groups II and III compared with Group I. TOS values were lower in Group V compared with Group IV. Administration of Tempol at a dose of $50 \mathrm{mg} / \mathrm{kg}$ was more effective than at a dose of $30 \mathrm{mg} / \mathrm{kg}$, and this difference was statistically significant. OSI values were significantly lower in Group IV and Group V compared with Group III (Dokuyucu et al. 2014) demonstrated that TOS and OSI increased and TAS decreased in ischemia and I/R groups compared with the sham group.

Figure 1 presents histopathological results of the study. Torsion has been shown to cause venous congestion, hemorrhage, and neutrophil infiltration. Our results indicated that the values for edema, vascular congestion, hemorrhage, and cell inflammation were higher in Group III compared with Group I. In addition, the cellular scoring system suggested that ovarian damage was more severe in the $\mathrm{I} / \mathrm{R}$ group than in the ischemia group.

In our study, infiltration of inflammatory cells significantly increased in the $\mathrm{I} / \mathrm{R}$ group and significantly decreased in Group V compared with Group III. These results also suggested that the administration of tempol at a dose of $50 \mathrm{mg} / \mathrm{kg}$ was more effective than at a dose of $30 \mathrm{mg} / \mathrm{kg}$ and the difference was statistically significant. In our study, infiltration of inflammatory cells increased in the I/R group. After ischemia, when reperfusion is provided, 
infiltration of inflammatory cells and the production of reactive oxygen radicals occur in the tissue (Carden and Granger 2000).

Several antioxidant and anti-inflammatory treatments have been used for the protection of ovarian tissue against I/R injury (Akdemir et al. 2015). Formation of ROS is reduced by antioxidant therapies, thereby leading to cell protection. Tempol is a low molecular weight and a SOD-mimetic antioxidant agent accumulating in the cytosol in $\mathrm{I} / \mathrm{R}$ injury. Tempol also scavenges free radicals and reduces the release of oxidant free radicals (Teke et al. 2008). Administration of tempol has been shown to significantly reduce organ injuries caused by $I / R$ in gastric mucosa, gallbladder, intestine, myocardium, kidney, and liver (Abdallah et al. 2009; Fujii et al. 2005; Gomez-Pinella et al. 2010; McCormick et al. 2006; Sepodes et al. 2004; Teke et al. 2008). Beneficial effects of tempol depend on the scavenging hydroxyl radicals within the cell and these effects are have been shown to reduce tissue damage due to inflammation (Erbis et al. 2015). Tempol removes ROS and inhibits lipid peroxidation, and all of these processes play a major role in the inhibition of oxidative injury (Zhao et al. 2015).

In conclusion, our results demonstrated that Tempol decreases I/R injury in rat ovary. In addition, the results also suggested that the administration of tempol at a dose of $50 \mathrm{mg} / \mathrm{kg}$ is more effective than at a dose of $30 \mathrm{mg} / \mathrm{kg}$. The present study is the first one to report on the effects of Tempol in ovarian I/R models. Tempol is a protective antioxidant agent for ovarian tissue in I/R injury. However, further studies are needed to explore the benefits of tempol in both ischemic ovarian tissues and thus reproduction. Moreover, further studies may also provide greater amount of knowledge about the beneficial clinical effects of tempol on the ovarian tissues exposed to ischemia-reperfusion injury. Our findings indicate that tempol might be useful in clinical practice, particularly in the treatment of damage resulting from ovarian torsion. 


\section{References}

Abdallah, D.M., El Abhar, H.S., and Abdel-Aziz, D.H. 2009. TEMPOL, a membranepermeable radical scavenger, attenuates gastric mucosal damage induced by ischemia/ reperfusion: a key role for superoxide anion. Eur. J. Pharmacol. 603:93-97.

Abouzied, M.M., Eltahir, H.M., Taye, A., and Abdelrahman M.S. 2016. Experimental evidence for the therapeutic potential of tempol in the treatment of acute liver injury. Mol. Cell. Biochem. 411(1-2):107-15.

Aebi, H. 1974. Catalase. In Methods of enzymatic analysis. Edited by H.U. Bergmeyer. Academic, New York. pp. 673-677.

Akdemir, A., Sahin, C., Erbas, O., Yeniel, A.O., and Sendag, F. 2015. Is ursodeoxycholic acid crucial for ischemia/reperfusion-induced ovarian injury in rat ovary? Arch. Gynecol. Obstet. 292:445-450.

Bradford, M.M. 1976. A rapid and sensitive method for the quantitation of microgram quantities of protein utilizing the principle of protein-dye binding. Anal. Biochem. 7:248254.

Carden, D.L., and Granger, D.N. 2000. Pathophysiology of ischemia-reperfusion injury. J. Pathol. 190:255-66.

Cosar. E., Sahin, F.K., Köken, G., Toy, H., Basarali, K., and Büyükbas, S. 2007. The protective effect of alpha-lipoic acid in experimental ovarian ischaemia-reperfusion injury. Aust. N.Z. J. Obstet. Gynaecol. 47: 499-503.

Demirbag, R., Gur, M., Yilmaz, R., Kunt, A.S., Erel, O., and Andac, M.H. 2007. Influence of oxidative stress on the development of collateral circulation in total coronary occlusions. Int. J. Cardiol. 116:14-9.

Dokuyucu, R., Karateke, A., Gokce, H., Kurt, R.K., Ozcan, O., Ozturk, S., et al. 2014. Antioxidant effect of erdosteine and lipoic acid in ovarian ischemia-reperfusion injury. Eur. J. Obstet. Gynecol. Reprod. Biol. 183: 23-27.

Draper, H.H., and Hadley, M. 1990. Malondialdehyde determination as index of lipid peroxidation. Methods Enzymol. 186:421-31.

Erbıs, H., Aykota, M.R., Ozturk, B., Kabay, B., Sungurtekin, U., Ozden, A., et al. 2015. Effects of Tempol on Experimental Acute Necrotizing Pancreatitis Model in Rats. J. Invest. Surg. 28(5):268-275.

Erel, O. 2005. A new automated colorimetric method for measuring total oxidant status. Clin. Biochem. 38:1103-11. 
Erel, O. 2004 A novel automated method to measure total antioxidant response against potent free radical reactions. Clin. Biochem. 37:112-9.

Ergun, Y., Koc, A., Dolapcioglu, K., Akaydin, Y., Dogruer, G., Kontas, T., Kozlu, T., and Aslan, E. 2010. The protective effect of erythropoietin and dimethylsulfoxide on ischemia-reperfusion injury in rat ovary. Eur. J. Obstet. Gynecol. Reprod. Biol. 152:18690.

Fujii, T., Takaoka, M., Ohkita, M., and Matsumura, Y. 2005. Tempol protects against ischemic acute renal failure by inhibiting renal noradrenaline overflow and endothelin-1 overproduction. Biol. Pharm. Bull. 28:641-645.

Gomez-Pinilla, P.J., Camello, P.J., Tresguerres, J.A.F., and Pozo, M.J. 2010. Tempol protects the gallbladder against ischemia/reperfusion. J. Physiol. Biochem. 66: 161-172.

Guven, S., Muci, E., Unsal, M.A., Yulug, E., Alver, A., Kadioglu Duman, M., and Mentese, A. 2010. The effects of carbon dioxide pneumoperitoneum on ovarian blood flow, oxidative stress markers, and morphology during laparoscopy: a rabbit model. Fertil. Steril. 93: 1327-32.

Halici, Z., Karaca, M., Keles, O.N., Borekci, B., Odabasoglu, F., Suleyman, H., et al. 2008. Protective effects of amlodipine on ischemia-reperfusion injury of rat ovary: biochemical and histopathologic evaluation. Fertil. Steril. 90: 2408-2415.

Hibbard, L.T. 1985. Adnexal torsion. Am. J. Obstet. Gynecol. 152:456-61.

Karataş, Y., Seçilmiş, M.A., Karayaylali, I., Doran, F., Büyükafşar, K., Singirik, E., Sagliker, Y., and Dikmen, A. 2004. Effect of tempol (4-hydroxy tempo) on gentamicin-induced nephrotoxicity in rats. Fundam. Clin. Pharmacol. 18: 79-83.

Keskin Kurt, R., Dogan. A.C., Dogan. M., Albayrak. A., Kurt. S.N., Eren, F., et al. 2015. Protective Effect of Colchicine on Ovarian Ischemia-Reperfusion Injury: An Experimental Study. Reprod. Sci. 22(5): 545-550.

McCormick, J., Barry, S.P., Sivarajah, A., Stefanutti, G., Townsend, P.A., Lawrence, K.M., et al. 2006. Free radical scavenging inhibits STAT phosphorylation following in vivo ischemia/ reperfusion injury. FASEB J. 20:2115-17.

Oelsner, G., and Shashar, D. 2006. Adnexal torsion. Clin. Obstet. Gynecol. 49:459-63.

Oral, A., Odabasoglu, F., Halici, Z., Keles, O.N., Unal, B., Coskun, A.K., et al. 2011. Protective effects of montelukast on ischemia-reperfusion injury in rat ovaries subjected to torsion and detorsion: biochemical and histopathologic evaluation. Fertil. Steril. 95(4):1360-1366. 
Ozat, M., Gungor, T., Barun, S., Demirogullari, B., Sokmensuer, L.K., Gulbahar, O., Gursoy, D., and Muftuoglu, S. 2009. The effects of iloprost, a prostacyclin analogue, in experimental ischaemia/reperfusion injury in rat ovaries. Exp. Toxicol. Pathol. 61:519-27.

Paglia, D.E., and Valentine, W.N. 1967. Studies on the quantitative and qualitative characterization of erythrocyte glutathione peroxidase. J. Lab. Clin. Med. 70:158-170.

Sadoshima, J. 2008. The role of autophagy during ischemia/reperfusion. Autophagy, 4(4):402-403.

Sahin, F.K., Cosar, E., Koken, G., Toy, H., Basarali, K., and Buyukbas S. 2008. Protective effect of aprotinin on ischemia-reperfusion injury in rat ovary. J. Obstet. Gynaecol. Res. 34:794-800.

Sepodes, B., Maio, R., Pinto, R., Marques, C., Mendes-do-Vale, J., McDonald, M.C., Thiemermann, C., and Mota-Filipe, H. 2004. Tempol, an intracelullar free radical scavenger, reduces liver injury in hepatic ischemia-reperfusion in the rat. Transplant Proc. 36:849-853.

Somuncu, S., Cakmak, M., Dikmen, G., Akman, H., and Kaya, M. $2008 . \quad$ Ischemiareperfusion injury of rabbit ovary and protective effect of trapidil: an experimental study. Pediatr. Surg. Int. 24:315-8.

Teke, Z., Kabay, B., Ozden, A., Yenisey, C., Bir, F., Demirkan, N.C., Bicakci, T., and Erdem, E. 2008. Effects of tempol, a membrane-permeable radical scavenger, on local and remote organ injuries caused by intestinal ischemia/reperfusion in rats. J. Surg. Res. 149:259-271.

Zhao, B., Pan, Y., Wang, Z., Tan, Y., and Song, X. 2015. Intrathecal Administration of Tempol Reduces Chronic Constriction Injury-Induced Neuropathic Pain in Rats by Increasing SOD Activity and Inhibiting NGF Expression. Cell. Mol. Neurobiol. 36(6):893-906.

Zweier, J.L., Flaherty, J.T., and Weisfeldt, M.L. 1987. Direct measurement of free radical generation following reperfusion of ischemic myocardium. Proc. Natl. Acad. Sci. U. S. A. 84(5):1404-1407. 
Fig. 1. Histological sections of rat ovaries stained with hematoxylin and eosin.

1. Group I: Sham group. No pathological changes were detected. 2. Group II: Vascular congestion, hemorrhage, inflammatory cell infiltration (big arrow), edema (little arrow) increased in the ischemia group. 3. Group III: Vascular congestion, hemorrhage, inflammatory cell infiltration (big arrow), edema (little arrow) were observed and all of them increased in the ischemia/reperfusion group. 4. Group IV: Decreased vascular congestion, edema, hemorrhage and inflammatory cell infiltration were detected in the Tempol $30 \mathrm{mg} / \mathrm{kg}$ group. 5. Group V: Vascular congestion, edema, hemorrhage and inflammatory cell infiltration significantly decreased in the Tempol $50 \mathrm{mg} / \mathrm{kg}$ group. 


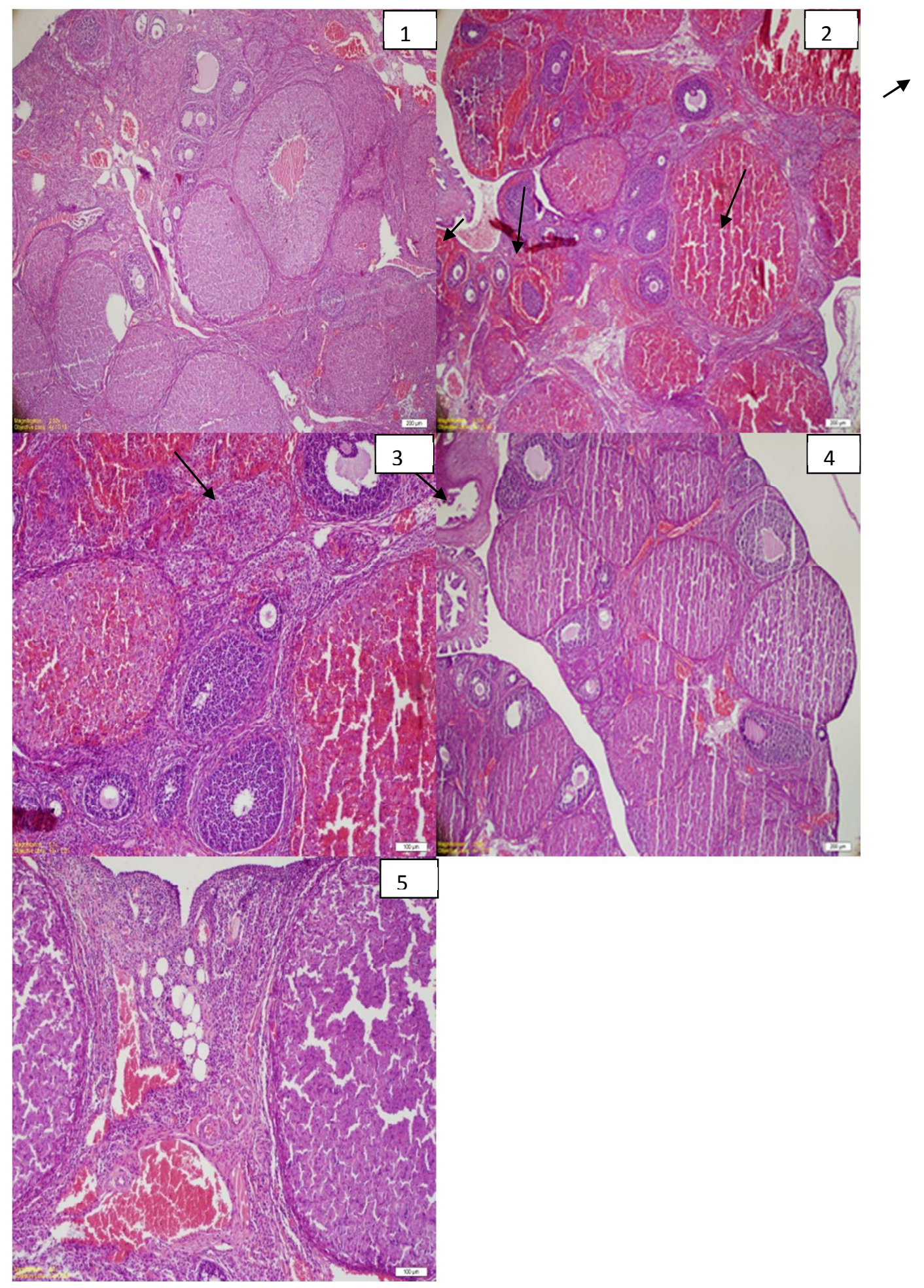

Figure 1. 
Table 1. TAS, TOS, OSI in all groups ( $n=8$ each)

\begin{tabular}{llllll}
\hline Parameters & Group I & Group II & Group III & Group IV & Group V \\
\hline TAS & $1.28 \pm 0.07$ & $1.08 \pm 0.02^{*}$ & $1.14 \pm 0.04$ & $1.18 \pm 0.04$ & $1.08 \pm 0.02^{*}$ \\
TOS & $35.8 \pm 4.06$ & $52.3 \pm 4.19^{*}$ & $89.5 \pm 3.13^{*}$ & $58.1 \pm 4.43^{*}$ & $40.1 \pm 2.76^{*}$ \\
OSI & $2.81 \pm 0.3$ & $4.82 \pm 0.38^{*}$ & $7.87 \pm 0.32^{*}$ & $4.92 \pm 0.37^{*}$ & $3.74 \pm 0.31^{*}$ \\
\hline
\end{tabular}

Data were expressed as Mean \pm SE.

TAS: Total antioxidant status ( $\mu$ mol Trolox Eq/l)

TOS: Total oxidant status ( $\mu \mathrm{mol} \mathrm{H} 2 \mathrm{O} 2 \mathrm{Eq} / \mathrm{l})$

OSI: Oxidative stress index

TAS

${ }^{*} P=0.04$ Group I-2

${ }^{*} P=0.03$ Group I-5
TOS

${ }^{*} p=0.034$ Group I-2

${ }^{*} p<0.001$ Group I-3

$* p=0.001$ Group I-4

$*_{p}<0.001$ Group III-4

${ }^{*} p<0.001$ Group III-5

${ }^{*} p=0.013$ Group IV -5
OSI

$* p=0.002$ Group I-2

$* p<0.001$ Group I-3

$* p=0.001$ Group I-4

${ }^{*} p<0.001$ Group II-3

$* p<0.001$ Group III-4

${ }^{*} p=0.034$ Group III-5 
Table 2: Levels of biochemical parameters in all groups ( $n=8$ each)

\begin{tabular}{llclll}
\hline Parameters & Group I & Group II & Group III & Group IV & Group V \\
\hline MDA & $14.04 \pm 0.7$ & $24.1 \pm 0.9^{*}$ & $39.0 \pm 1.5^{*}$ & $26.3 \pm 0.6^{*}$ & $24.5 \pm 0.8^{*}$ \\
Catalase & $4.83 \pm 0.17$ & $2.7 \pm 0.1^{*}$ & $1.42 \pm 0.1^{*}$ & $3.04 \pm 0.15^{*}$ & $2.78 \pm 0.15^{*}$ \\
GSH & $47.0 \pm 1.9$ & $38.9 \pm 1.4^{*}$ & $12.02 \pm 0.5^{*}$ & $22.4 \pm 1.2^{*}$ & $18.2 \pm 0.9^{*}$ \\
\hline
\end{tabular}

Data were expressed as Mean \pm SE.

MDA: Malondialdehyde ( $\mathrm{nmol} / \mathrm{g}$ tissue)

Catalase: $(\mathrm{k} / \mathrm{g}$ tissue $)$

GSH: Reduced glutathione (U/g tissue)

MDA

$*_{p}<0.001$ Group I-2,3,4,5

$*_{p}<0.001$ Group II-3

$*_{p}<0.001$ Group III-4

$*_{p}<0.001$ Group III-5
Catalase

$*_{p}<0.001$ Group I-2,3,4,5

$* p<0.001$ Group II-3

$*_{p}<0.001$ Group III-4

${ }_{*}^{*}<0.001$ Group III-5
GSH

$*_{p}<0.001$ Group I-2,3,4,5

${ }^{*} p<0.001$ Group II-3,4,5

${ }^{*} p<0.001$ Group III-4

${ }^{*} p=0.014$ Group III-5 
Table 3. Histopathological evaluation of rat ovarian tissues in all groups

\begin{tabular}{lccccc}
\hline & $\begin{array}{c}\text { Group I } \\
\text { (control) }\end{array}$ & Group II & Group III & Group IV & Group V \\
& $0.5 \pm 0.1$ & $1.5 \pm 0.1$ & $2.1 \pm 0.2^{*}$ & $1.8 \pm 0.2^{*}$ & $1.3 \pm 0.2$ \\
\hline Edema & $0.8 \pm 0.1$ & $1.7 \pm 0.1^{*}$ & $2.3 \pm 0.1^{*}$ & $2.2 \pm 0.2^{*}$ & $1.5 \pm 0.1^{*}$ \\
\hline $\begin{array}{l}\text { Vascular } \\
\text { congestion }\end{array}$ & $0.0 \pm 0.0$ & $0.3 \pm 0.1^{*}$ & $1.8 \pm 0.3^{*}$ & $1.0 \pm 0.3$ & $0.5 \pm 0.2^{*}$ \\
\hline Hemorrhage & $0.0 \pm 0.0$ & $0.6 \pm 0.1^{*}$ & $1.8 \pm 0.2^{*}$ & $1.1 \pm 0.1^{*}$ & $0.6 \pm 0.2^{*}$ \\
\hline $\begin{array}{l}\text { Infiltration of } \\
\text { inflammatory cells }\end{array}$ & & & & & \\
\hline $\begin{array}{l}\text { Follicle } \\
\text { degeneration }\end{array}$ & $19.2 \pm 4.2$ & $23.5 \pm 1.9$ & $26.8 \pm 2.6$ & $22.2 \pm 2.3$ & $21.0 \pm 2.4$ \\
\hline
\end{tabular}

Data were expressed as Mean \pm SE.

Edema Vascular congestion Hemorrhage Inf. of inflam. cells

${ }^{*} p=0.001$ Group I-3 $\quad{ }^{*} p=0.017$ Group I-2 $\quad{ }^{*} p<0.001$ Group I-3 $\quad{ }^{*} p<0.001$ Group I-3

${ }^{*} p=0.001$ Group I-4 $\quad{ }^{*} p=0.001$ Group I-3 $\quad *_{p}=0.002$ Group II-3 $\quad{ }^{*} p=0.001$ Group I-4

${ }^{*} p<0.001$ Group I-4 $\quad * p=0.005$ Group III-5 ${ }^{*} p<0.001$ Group II-3

${ }^{*} p=0.017$ Group III-5 $\quad{ }^{*} p<0.001$ Group III-5 